\title{
A DOR E ALEGRIA DE NASCER.
}

\author{
Amparo Caridade ${ }^{1}$ \\ PAIN AND JOY OF BIRTH.
}

Nascer, viver e morrer, não são momentos datados na vida, são processos que acompanham o existir do ser humano. Existimos enquanto corpos, enquanto sujeitos, enquanto totalidades. Enquanto corpo, nascemos um dia de um outro corpo, mas enquanto sujeitos, nascemos a cada dia, a cada realização, a cada descoberta, a cada gesto. Nascemos quando criamos algo, ou quando fazemos reparação de atos indevidos. Nascemos quando colocamos no mundo um novo ser.

Nascemos quando produzimos bem-estar. Nascer, não é apenas o ato de chegar ao Mundo, é um processo que se inicia aí, mas que só termina com a morte. Na verdade, nascemos, vivemos e morremos a cada instante. Viver, é também um processo, e ele não acontece apenas no ato físico de ter um corpo vivo. O corpo pode estar vivo, mas o sujeito pode ter sido sacrificado nele.

Vivemos como sujeitos quando somos nós mesmos, quando amamos o que fazemos. Vivemos nos projetos que temos, nas contribuições que damos à vida, ao mundo, às relações. Vivemos naquilo que construímos e deixamos atrás de nós, como ação fincada no solo da coletividade, como marca identitária da passagem que fizemos pelo planeta. Morremos quando o corpo deixa de viver, mas morremos sobretudo, nas negações que fazemos de nós mesmos, nas anulações do eu, nas derrotas da auto-estima, na banalização da vida.

A dor como a alegria tornam-se parceiras do existir, na costumeira solenidade do cotidiano, desde o nascer, o viver até o morrer. Esses processos são acompanhados de emoções intensas quando a elas nos permitimos. $\mathrm{O}$ bebê nasce em meio a dores e intensas alegrias, dos pais, dos familiares, dos avós. Quando o evento de um nascimento querido, acontece distante de nós,

\footnotetext{
- Artigo publicado na seção Opinião do Diário de Pernambuco - 21 de fevereiro de 2010

${ }^{1}$ Professora da UNICAP.
} 
essas emoções invadem o imaginário numa presença totalizadora, numa proximidade quase alucinatória.

O telefone permite ouvir a voz, o choro, a floricultura faz presente a ternura, a internet deixa ver fotos de preciosos momentos. São mediadores desse universo encantado, mas não eliminam a expectativa, a espera do contato. À distância vivem-se as inquietâncias do ato de nascer, vivem-se as dores do parto, as contrações, respirações, num acompanhamento ansioso, numa espera quase interminável. Nascer dá trabalho. Otto Rank referia-se ao nascimento como sendo um momento traumático para o bebê. Mas, nascer também mobiliza, encanta, modifica os afetos, os sentidos o mundo e os outros.

O que acontece ao bebê, acontece também a cada um de nós, em cada nascimento que fazemos para uma etapa melhor do existir. O momento pode ser doloroso, mas também fértil e promissor de alegrias intensas. O mundo da imaginação fútil postula que a vida seja sem dor, que seja fácil, o que pode se tornar uma espera alienante. Nascer dói, mesmo assim não temos escolha. Se o bebê não nasce, morrerá. Nascemos e renascemos a cada instante, sem o que, estaremos abortando o próprio eu.

A vida se recicla a cada nascimento. O bebê é promessa. Promessa de imortalidade, caricatura da felicidade impossível. O filho, o neto, recicla a família e seus afetos. Nasceu Fernandinho, cheio de promessa e luz. É puro encanto aos olhos de todos que amam seu vir a ser. É promessa de ternura tanta, que chego a sentí-lo, sem ainda tê-lo tido nos braços.

Nasceu Nathan, que em hebraico significa "Deus me deu". Os filhos são doações de Deus ao mundo necessitante de renovação, de paz, de ternura, de amizade. Seria pobre esse mundo, se os bebês não viessem dar-lhe nova luz! Popularmente diz-se que a mulher "dá a luz". O bebê é a luz que a mulher dá ao mundo. Na sabedoria do povo, intui-se a renovação que um novo ser traz à vida. "Cada criança que vem ao Mundo diz: Deus ainda espera alguma coisa do homem" diz Tagore. 